Article

\title{
COVID-19 and International Diversification: A New Paradigm for Multinationals
}

\author{
Kaitlyn DeGhetto \\ 1 University of Dayton, USA \\ Keywords: international diversification, covid-19, multinational corporations, institutions, business continuity \\ https://doi.org/10.46697/001c.17941
}

\section{AIB Insights}

Vol. 20, Issue 3, 2020

\begin{abstract}
COVID-19 has challenged longstanding assumptions about multinationals' international diversification strategies. Unlike corruption or war, this new type of uncertainty is unavoidable. All countries are affected. And, throughout the pandemic, having a global workforce has created additional challenges related to managing diverse policies, resources, and cultures. Going forward, executives of multinationals will first and foremost consider business continuity when selecting investment locations. Multinationals, especially those in service-based industries, likely will scale down their global operations and focus on countries with infrastructures that support remote work and sustaining healthy populations. Key insights come from an executive who managed his firm's COVID-19 response.
\end{abstract}

Executives and policymakers must consider how the COVID-19 pandemic will change multinational corporations' (MNCs') international diversification strategies. Historically, when MNCs chose locations for foreign investments to access labor they considered key factor such as: (1) the cost of doing so (e.g., wage rates), (2) the quality of the resources (e.g., employee skills), and (3) institutional uncertainty (e.g., economic downturns, political uncertainty). With this in mind, MNCs lived by the adage "don't put all your eggs in one basket.” This way, when facing increased uncertainty in one country or region, the other investment locations would not be exposed, protecting the firm (Rugman, 1976). The COVID-19 pandemic has caused this strategy to implode. With this new type of uncertainty, no country is immune.

As opposed to MNCs remaining protected by having geographically diverse locations, additional challenges arose when COVID-19 began to spread globally. They were forced to manage shutdowns, rapidly changing government policies, and health crises in multiple countries. Due to the reality of these unforeseen challenges, going forward, MNCs will first and foremost consider the likelihood of continuing business activities in the face of global pandemics, such as COVID-19. This means rethinking the weight of other factors, such as low wage rates. And, as opposed to scaling up, scaling down the geographic diversification of global workforces. This new paradigm shift likely will result in MNCs focusing on countries that best managed COVID-19 and are equipped to support remote workforces. Remote work is especially relevant for service-based firms because the majority of employees are not required to work from a specific location, such as a manufacturing facility. Moreover, MNCs will focus on developing strategic flexibility. Adapting quickly in the face of countries' diverse responses will be imperative.

\section{INTERNATIONAL DIVERSIFICATION: KEY CONSIDERATIONS}

For decades, it has been assumed that MNCs should look at their foreign operations like they would an investment portfolio; international diversification reduces risk (Rugman, 1976). If one market is disrupted and workers are unable or unwilling to work at full capacity, other markets can be utilized. Researchers also have found that MNCs, in an effort to limit business disruptions and unknowable circumstances, tend to avoid countries or regions with high levels of institutional uncertainty, such as policy-related risk (e.g, corruption) and violent conflict (e.g., war) (e.g., DeGhetto, Lamont, \& Holmes, 2020; Demirbag, Glaister, \& Tatoglu, 2007; North, 1990; Oetzel \& Getz, 2012).

COVID-19 and potential future pandemics are different, however, and highlight issues with both of these previously held assumptions and related strategies. First, in many cases, international diversification of operations increased complexity. As the COVID-19 outbreak was declared a pandemic, all markets were affected, and almost simultaneously. Instead of the upside of being able to rely on workforces in other countries, MNCs faced the downside of managing disruptions in virtually every country in which their employees were located. Second, COVID-19 cannot be isolated and avoided, such as with policy risk or war. Regardless of country or region, managing it is imperative. For these reasons, both researchers and executives need to rethink 1) how they perceive institutional uncertainty, with special consideration given to countries' responses to COVID-19, 2) how they consider it against other investment factors, and ultimately, 3) how to reconfigure their international operations going forward.

\section{MANAGING COVID-19}

To highlight the challenges of managing this new type of uncertainty with a geographically diverse workforce, I summarize the experience of a US-based MNC with approximately 50,000 employees in 20+ countries. This is a service-based company focused on business process outsourcing. They provide customer support and engagement solutions (e.g., call center support, training services, customer acquisition, and related software) to other large, global corporations in a variety of industries (e.g., banking, automo- 
tive, health care, travel, government). Like many MNCs, the continuation of their business activities is crucial - not only to their own survival, but the survival of many of their customers. The following insights come from an interview with one of the firm's executives who oversaw the firm's response to COVID-19.

As countries began closing borders and issuing stay-athome orders, executives worked around the clock to transition the majority of their employees to remote or "socially distanced” work environments. In countries such as the Philippines, this process included understanding who had the ability to work from home and then negotiating with government officials to get through checkpoints so deliveries of computers, WiFi hotspots, and other equipment could be made to thousands of homes. For those unable to work from home, the company worked to quickly renovate buildings with living spaces, including sleeping quarters, entertainment options, stocked kitchens, and laundry rooms. Another group of employees were housed in hotels so that they could walk to work or work directly from the hotels.

In other countries, such as the US, many employees were converted to remote work, but customers in governmentdeemed essential industries (e.g., banking) required that employees servicing their accounts continue working from office buildings. This resulted in reconfiguring office spaces to account for social distancing and implementing stringent cleaning procedures. Still, many employees felt unsafe and were hesitant to come to the office. Significant issues also arose when the US government's CARES Act came into effect. Many employees and potential hires were reluctant to work because of the elevated government assistance (i.e., $\$ 600$ per week unemployment bonus) (Maher, 2020), and stay-at-home orders made it increasingly difficult to hire and train personnel.

Challenges faced in other countries where the firm has employees included not having access to enough power sources in employees' homes, government regulations limiting employees' abilities to work from home, and employees refusing to continue work with the presence of health concerns and new demands (e.g., children at home). On top of these obstacles, standard operating procedures related to cleaning buildings, managing security, fixing IT issues, and responding to sick employees became outdated or incompatible overnight and had to be reworked.

With COVID-19 escalating across the world, these challenges and many others had to be addressed within days, and often within hours. Moreover, government policies and social norms are different in each country and had to be carefully navigated, only increasing the complexity faced. For example, in some countries the cultural norm is that employees are not obligated to work when seemingly more pressing issues arise; in others, the norm is that responsibility to one's company come first. Differences also exist related to whether the government or employers are more responsible for providing a safety net and direction to employees in times of crisis.

In the end, this company was able to keep the majority of their employees working and clients served. But, it wasn't easy, and the long-term costs are still unknown. As one company executive said, "Every country scrambled to get things done and address the pandemic within the parameters of their social norms and resource constraints. We made it work. But, in the future, continuity of business will be our - and I believe our clients' - number one concern."

\section{COUNTRY-LEVEL FACTORS}

History teaches us valuable lessons about the future. MNCs will reflect on how countries initially responded to the COVID-19 pandemic when making future investment decisions. In addition to variance in government decisions related to COVID-19, the existing infrastructure in countries shaped the effectiveness of MNCs' responses and outcomes. Importantly, early data reveals which countries may be best equipped to support business continuity throughout the remainder of the COVID-19 pandemic and in similar, future situations. Table 1 presents business continuity data for countries across regions.

\section{GOVERNMENT SHUTDOWNS}

MNCs will consider the extent of shutdowns and how they were managed. For example, in Europe, Germany kept many of their businesses running with social distancing and other safety precautions (e.g., testing, contact-tracing, masks) in place. As detailed in a Wall Street Journal report, German firm, ebm-papst Group, ran at $80 \%$ capacity during the country's national shutdown, and only 15 of their 6,700 workers (0.2\%) contracted COVID-19 during this period (Fairless, 2020). Even with fewer restrictions than other European nations (e.g., France, Italy, Spain), Germany's death rate from COVID-19 remains much lower. Although a myriad of factors are involved (e.g., average age of citizens, prevalence of preexisting conditions), this comparison sheds lights on effectively balancing health and economic needs.

MNCs likely will also consider whether countries enacted nationwide shutdowns and related policies, or left it to local leaders. Although in some cases fragmented policies are beneficial to businesses, especially in larger countries, additional complexities are created because the timing and magnitude of shutdowns could differ substantially from city-to-city. Related, travel restrictions will be considered, both within the country and internationally. Some countries, such as the US, largely allowed free flow of people within the country. Others, such as France and the Philippines, introduced greater restrictions on domestic travel. Remote work becomes even more critical to employ when tight travel restrictions are in place.

\section{GOVERNMENT (FINANCIAL) SUPPORT}

Stimulus packages and how money is to be allocated differs significantly across countries. MNCs will seek support which helps them to survive after the pandemic eases and retain employees. As noted previously, although there arguably were substantial benefits to business from the US government's CARES Act (e.g., small business loans, tax breaks), it also created problems with retaining employees throughout the pandemic and bringing them back when restrictions eased (Maher, 2020). Other approaches implemented by governments to avoid layoffs included subsidizing wages and moving employees to short-time work. For example, to avoid mass layoffs, the UK government offered to pay $80 \%$ of salaries for employees who were retained. And, in Germany, Kurzarbeit (i.e., "short-time work") was implemented which allows employers to cut hours while the government covers the majority of wage expenses. When making long-term investments, MNCs also should consider how this support was funded because high levels of debt may result in future economic and/or political instability. 
TABLE 1. Country-Level Factors

\begin{tabular}{|c|c|c|c|c|c|c|c|c|c|}
\hline Country & $\begin{array}{l}\text { Broadband } \\
\text { subscriptions (per } \\
100)^{\mathrm{a}}\end{array}$ & $\begin{array}{l}\text { Download } \\
\text { speed (mbps, } \\
\text { avg) }\end{array}$ & $\begin{array}{l}\text { Household } \\
\text { size (avg) }\end{array}$ & $\begin{array}{l}\text { Hospital } \\
\text { beds (per } \\
1,000)^{\mathrm{a}}\end{array}$ & $\begin{array}{l}\text { Physicians } \\
\text { (per } \\
1,000)^{\mathrm{a}}\end{array}$ & $\begin{array}{l}\text { COVID-19 } \\
\text { cases; } \% \\
\text { deaths }^{d}\end{array}$ & $\begin{array}{l}\text { COVID- } 19 \% \text { deaths (of } \\
\text { total population) }\end{array}$ & $\begin{array}{l}\text { COVID-19 test } \\
\text { rate (per 1,000) }\end{array}$ & $\begin{array}{l}\text { Economic } \\
\text { Stimulus (\% } \\
\text { GDP) }\end{array}$ \\
\hline Argentina & 19.1 & 12.8 & 3.3 & 5 & 4.0 & $282,437(2.0)$ & 0.012 & 18.5 & 4.0 \\
\hline Australia & 30.7 & 37.4 & 2.5 & 3.8 & 3.6 & $23,035(1.6)$ & 0.001 & 207.7 & 9.9 \\
\hline Bangladesh & 6.3 & 5.7 & 4.5 & 0.8 & 0.5 & 274,525 (1.3) & 0.002 & 7.9 & $2.5^{*}$ \\
\hline Brazil & 14.9 & 13.0 & 3.3 & 2.2 & 2.1 & $\begin{array}{l}3,275,520 \\
(3.3)\end{array}$ & 0.050 & 11.9 (July) & 8.0 \\
\hline Canada & 39.0 & 42.5 & 2.4 & 2.7 & 2.6 & $121,652(7.4)$ & 0.024 & 126.6 & 9.8 \\
\hline China & 28.5 & ND & 3.4 & 4.2 & 1.8 & $89,761(5.2)$ & $<0.001$ & ND & 2.5 \\
\hline Colombia & 13.5 & 10.0 & 3.5 & 1.5 & 2.1 & $445,111(3.3)$ & 0.029 & 42.1 & 2.8 \\
\hline France & 44.8 & 25.2 & 2.2 & 6.5 & 3.2 & $\begin{array}{l}202,118 \\
(15.0)\end{array}$ & 0.045 & 12.7 (May) & 5.0 \\
\hline Germany & 41.1 & 22.6 & 2.1 & 8.3 & 4.2 & $223,453(4.1)$ & 0.011 & 110.6 & 4.9 \\
\hline Guatemala & 3.1 & 10.8 & 4.8 & 0.6 & 0.4 & $62,313(3.8)$ & 0.014 & ND & 3.4 \\
\hline Israel & 28.8 & 13.6 & 3.1 & 3.1 & 3.2 & $88,488(0.7)$ & 0.007 & 227.2 & 6.1 \\
\hline Italy & 28.1 & 19.9 & 2.4 & 3.4 & 4.1 & $\begin{array}{l}253,438 \\
(14.0)\end{array}$ & 0.059 & 73.7 & 1.4 \\
\hline Japan & 32.6 & 33.0 & 2.3 & 13.4 & 2.4 & $54,714(2.0)$ & 0.001 & 11.6 & 21.1 \\
\hline Kenya & 0.7 & 10.1 & 3.6 & 1.4 & 0.2 & $29,849(1.6)$ & 0.001 & 7.0 & 0.4 \\
\hline Korea & 41.6 & 52.4 & 2.5 & 11.5 & 2.4 & $15,318(2.0)$ & 0.001 & 32.5 & $4.7^{*}$ \\
\hline Malaysia & 8.6 & 11.5 & 4.6 & 1.9 & 1.5 & 9,175 (1.4) & $<0.001$ & 34.4 & 2.8 \\
\hline Mexico & 14.6 & 14.9 & 3.7 & 1.5 & 2.2 & $\begin{array}{l}511,369 \\
(10.9)\end{array}$ & 0.044 & 8.4 & 0.7 \\
\hline $\begin{array}{l}\text { New } \\
\text { Zealand }\end{array}$ & 34.7 & 27.3 & 2.7 & 2.8 & 3.6 & $1,271(1.7)$ & $<0.001$ & 124.0 & 21.3 \\
\hline Philippines & 3.7 & 7.0 & 4.2 & 1.0 & 1.3 & $157,918(1.6)$ & 0.002 & 14.5 & 3.2 \\
\hline Qatar & 9.6 & 24.6 & ND & 1.2 & 0.0 & $114,809(0.2)$ & 0.007 & 191.3 & 13.0 \\
\hline $\begin{array}{l}\text { South } \\
\text { Africa }\end{array}$ & 1.9 & 15.0 & 3.4 & 2.8 & 0.9 & $583,653(2.0)$ & 0.020 & 57.3 & $10.0^{*}$ \\
\hline Turkey & 16.3 & 17.1 & 4.1 & 2.7 & 1.8 & $248,117(2.4)$ & 0.007 & 67.9 & 1.5 \\
\hline U.K. & 39.6 & 21.7 & 2.3 & 2.8 & 2.8 & $\begin{array}{l}316,371 \\
(13.1) \\
\end{array}$ & 0.062 & 174.0 & $15.0^{*}$ \\
\hline U.S. & 33.8 & 21.3 & 2.5 & 2.9 & 2.6 & $\begin{array}{l}5,258,565 \\
(3.2)\end{array}$ & 0.051 & 202.3 & 11.0 \\
\hline
\end{tabular}

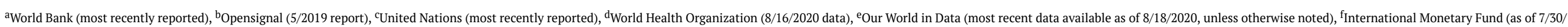
2020; *alternate source). ND=No data 


\section{STRENGTH OF THE HEALTH CARE SYSTEM}

Countries abilities to test, contact-trace, and treat sick employees is critical. As detailed in Table 1, the number of hospitals and physicians per country vary widely. For example, based on resources (i.e., hospital beds), it appears that South Korea and Japan are well-equipped to manage a pandemic, when compared to many other nations. The testing rates, cases, and death rates also indicate important information about countries' abilities to manage a health crisis.

\section{STABILITY OF HOME WORK ENVIRONMENTS}

Another factor is the increased and expedited need to rely on remote work. Advancements in technology and social norms in many parts of the world were already moving in that direction. COVID-19 accelerated this push and revealed which countries are prepared to do so. Experts expect COVID-19 challenges to continue well into 2021, and perhaps for years (Kissler, Tedijanto, Goldstein, Grad, \& Lipsitch, 2020). This reality creates uncertainty for MNCs related to continuing business activity in shared spaces. Likewise, MNCs will now account for the possibility of future pandemics.

To be successful and maintain business continuity, MNCs will need employees to work remotely as the "new normal" or be able to transition seamlessly when needed. As shown in Table 1, some countries are better prepared to do this than others, at least in terms of access to and quality of the internet. Moreover, due to common living arrangements in some countries, and in urban areas in general, it will be more difficult for employees to find space to effectively work from home.

\section{COUNTRY ATTRACTIVENESS: FUTURE PROJECTIONS}

We are still learning about the implications of COVID-19, and in the future, country-level conditions may differ. Importantly, MNCs should develop strategic flexibility. This is critical given frequent changes in the severity of outbreaks and changes in political leadership, which result in a variety of evolving government policies.

However, based on current conditions, it is possible to predict which countries may be best positioned to reduce uncertainty for MNCs dealing with COVID-19 or future pandemics. Although not meant to be an exclusive list, and understanding MNCs have other factors to consider (e.g., raw materials), I offer examples of countries that may present minimal uncertainty, moderate uncertainty, and heightened uncertainty going forward.

First, New Zealand and South Korea may be labeled as "minimal uncertainty" because they have environments equipped for remote work (e.g., home internet access and speed). Moreover, New Zealand has been commended for having very few cases (at one point temporarily eradicating the disease), and South Korea managed well (i.e., 305 deaths as of $8 / 16 / 20$ ) with less stringent shutdowns, when com- pared with other nations. Those falling under "moderate uncertainty" may include Germany and Argentina. As noted previously, during the first few months of the pandemic, Germany saw fewer COVID-19 fatalities (even with less restrictions) and conducted more tests than other European nations (e.g., France, Italy). Likewise, in comparison to many of their South American neighbors (e.g., Brazil, Colombia), Argentina has a robust medical system (e.g., physicians and hospital beds available) and fewer COVID-19 fatalities (as reported at the time Table 1 was created). Although there have been strict lockdowns, broadband connections are high for the region. Finally, countries with "heightened uncertainty" may include Mexico and Italy. As previously noted, Italy's government mandated strict lockdowns, and they still faced relatively high deaths as a percentage of cases and as a percentage of the population. Likewise, Mexico's fatality numbers outpaced other nations, with a low testing rate, and its institutional environment is less equipped for remote work, when compared with others.

\section{CONCLUSIONS}

COVID-19 has disrupted MNCs' global operations and workforces. Countries' varied responses to the pandemic represent a new form of institutional uncertainty which will fundamentally alter how international investment decisions are made. Many previously held assumptions are no longer valid. There is a need to weigh cost, quality, institutional factors, and other investment criteria differently. Business continuity will come to the forefront, especially for service-based firms due to their ability to leverage the benefits of remote work. To succeed in the months and years to come, MNCs will consider government reactions to the current crisis and infrastructure constraints. As a result, they likely will reconsider the diversification of their international workforces. MNCs also will focus on developing strategic flexibility so they can quickly adapt to various and frequently evolving government policies.

\section{ABOUT THE AUTHOR}

Kaitlyn DeGhetto, Ph.D. (kdeghetto1@udayton.edu), is an Assistant Professor of Management at University of Dayton. She received her Ph.D. in Strategy from Florida State University. Her research interests include firms' international investment decisions, country institutions, and corporate governance. Her work has been published in outlets such as Global Strategy Journal, Journal of Management Studies, Journal of World Business, Long Range Planning, and Strategic Management Journal.

Submitted: August 21, 2020 EST, Accepted: October 22, 2020 EST 


\section{REFERENCES}

DeGhetto, K., Lamont, B. T., \& Holmes, R. M. 2020. Safety risk and international investment decisions. Journal of World Business, 55(6): 101129.

Demirbag, M., Glaister, K. W., \& Tatoglu, E. 2007. Institutional and transaction cost influences on MNEs' ownership strategies of their affiliates: Evidence from an emerging market. Journal of World Business, 42(4): 418-434.

Fairless, T. 2020, May 6. How Germany kept its factories open during the pandemic. Wall Street Journal. https://www.wsj.com/articles/how-germanykept-its-factories-open-during-the-pandemic-115887 $\underline{74844}$.

Kissler, S. M., Tedijanto, C., Goldstein, E., Grad, Y. H., \& Lipsitch, M. 2020, April 14. Projecting the transmission dynamics of SARS-CoV-2 through the postpandemic period. Science. https://science.science mag.org/content/early/2020/05/11/science.abb5793.
Maher, K. 2020, May 8. Business struggles to lure workers away from unemployment. Wall Street Journal. https://www.wsi.com/articles/businesses-stru ggle-to-lure-workers-away-from-unemployment-115 88930202.

North, D. C. 1990. Institutions, institutional change and economic performance. Cambridge, UK: Cambridge University Press.

Oetzel, J., \& Getz, K. 2012. Why and how might firms respond strategically to violent conflict? Journal of International Business Studies, 43(2): 166-186.

Rugman, A. M. 1976. Risk reduction by international diversification. Journal of International Business Studies, 7: 75-80. 